\title{
Fortifikasi senyawa selenium pada jamur tiram coklat (Pleurotus pulmonarius dan Pleurotus sajor-caju)
}

\author{
Fortification of selenium compound in brown oyster mushroom (Pleurotus pulmonarius and Pleurotus \\ sajor-caju)
}

Firda DIMAWARNITA*), Yora FARAMITHA \& TRI-PANJI

\begin{abstract}
Pusat Penelitian Bioteknologi dan Bioindustri Indonesia, PT. Riset Perkebunan Nusantara, Jl. Taman Kencana No 01, Bogor
\end{abstract} 16128, Indonesia

Diterima tgl 15 Desember 2019 / disetujui tgl 7 April 2020

\begin{abstract}
Selenium (Se) is one of the most important micronutrients needed for human health. However, the content of Se compound in animals and plants is relatively small in order to meet recommended intakes of Se. Therefore, Se fortification in food source, such as mushroom, is needed. In this study, fortification was carried out by adding sodium selenite to the growth media (the mixture of sawdust and OPEFB) of brown oyster mushrooms included Pleurotus pulmonarius and Pleurotus sajor-caju, in various concentrations of 100,200,300, and 400 ppm. The results showed that the highest absorption of Se in P. pulmonarius and P. sojur caju (3.51 and $2.31 \%$, respectively) obtained from 200 ppm sodium selenite addition. High concentrations of sodium selenite in baglog media tend to inhibit mycellium growth and the production of mushroom fruiting body. The additions of 200 ppm sodium selenite in baglog media of $\mathrm{P}$. pulmonarius and P. sajor-caju were the best treatment in term of the fastest mycelium coverage in 40 and 37 days with the highest biological efficiency ratio (BER) value of 18.80 and $17.89 \%$, respectively.
\end{abstract}

[Keywords: mycellium, BER value, sodium selenite, fruiting body]

\begin{abstract}
Abstrak
Layu Senyawa selenium (Se) merupakan salah satu mikronutrien terpenting yang harus dipenuhi kebutuhannya dalam tubuh. Akan tetapi, kandungan senyawa Se pada hewan dan tumbuhan sangat kecil untuk memenuhi kebutuhan asupan Se yang dianjurkan. Oleh karena itu, fortifikasi Se pada sumber pangan seperti pada jamur diperlukan. Dalam penelitian ini, fortifikasi dilakukan dengan menambahkan sodium selenit ke dalam media pertumbuhan (campuran serbuk gergaji dan TKKS) jamur tiram coklat, yaitu Pleurotus pulmonarius dan
\end{abstract}

Pleurotus sajor-caju dengan berbagai konsentrasi, diantaranya: 100, 200, 300, dan 400 ppm. Hasil penelitian menunjukkan penyerapan Se tertinggi pada $P$. pulmonarius dan $P$. sojurcaju yaitu masingmasing sebesar 3,51 dan 2,31\% diperoleh dari penambahan sodium selenit $200 \mathrm{ppm}$. Konsentrasi sodium selenit yang tinggi pada media baglog cenderung menghambat pertumbuhan miselium dan produksi tubuh buah jamur. Penambahan sodium selenit sebanyak $200 \mathrm{ppm}$ pada media baglog $P$. pulmonarius dan $P$. sajor-caju merupakan perlakuan terbaik ditinjau dari waktu tercepat pertumbuhan miselium jamur menutupi media dalam baglog, yaitu masing-masing 40 dan 37 hari dengan nilai biological efficiency ratio (BER) tertinggi, yaitu 18,80 dan $17,89 \%$ secara berurutan.

[Kata kunci: miselium, nilai BER, sodium selenit, tubuh buah]

\section{Pendahuluan}

Kecukupan zat gizi mikro (mikronutrien) seperti $\mathrm{Fe}, \mathrm{Zn}, \mathrm{Ca}, \mathrm{Se}$, dan iodin sangat penting bagi tubuh (WHO \& FAO, 2006). Kasus kekurangan zat gizi mikro tersebar luas di negara-negara berkembang di dunia dan dapat terjadi pada seluruh usia, tetapi anakanak dan wanita usia subur (WUS) cenderung yang paling beresiko mengalami defisiensi mikronutrien. Menurut Dirjen Kefarmasian dan Alat Kesehatan Kementerian Kesehatan Republik Indonesia, kasus kekurangan zat gizi mikro tengah menjadi sorotan selama kurun waktu 5 tahun terakhir, kekurangan mikronutrien dapat mengakibatkan masalah kesehatan hingga kerugian ekonomi (Sitanggang, 2017). Kekurangan mikronutrien memiliki banyak efek buruk pada kesehatan manusia. Bahkan tingkat defisiensi mikronutrien pada tingkat sedang, berdampak serius pada organ fungsional manusia.

Salah satu mikronutrien yang penting bagi tubuh adalah Selenium (Se). Senyawa Se terdapat dalam

*) Penulis korespondensi: firda.dimawarnita@gmail.com 
tanah namun umumnya dalam bentuk tidak dapat larut (mengandung zat besi tinggi dan organik), terdapat pada tanah ber $\mathrm{pH}$ rendah dan daerah miring seperti pegunungan (Bhatia et al., 2013). Oleh sebab itu, bioavailabilitas tanaman dalam menyerap Se pun sedikit dan menyebabkan ketersediaan Se dalam tanaman sangat terbatas (Yin et al., 2019; El Mehdawi \& Pilon-Smits, 2012; Thiry et al., 2012). Kandungan Se pada tumbuhan berkisar $0,1-0,8 \mu \mathrm{g} / \mathrm{g}$ sedangkan pada hewan berkisar 0,1-1,5 $\mu \mathrm{g} / \mathrm{g}$ (WHO \& FAO, 2006). Kandungan tersebut masih sangat kecil dibandingkan dengan angka anjuran kecukupan mineral Se yang tertera pada Tabel Angka Kecukupan Gizi (AKG) dalam Permenkes RI No 28 Tahun 2019, yaitu 7-36 $\mu \mathrm{g}$ per hari (Kemenkes RI, 2019). Defisiensi Se dapat menyebabkan gangguan kesehatan seperti penyakit kardiovaskular, sindrom inflamasi, disfungsi tiroid, penurunan kesuburan dan penurunan fungsi kekebalan tubuh, rentan terinfeksi virus dan peningkatan resiko kanker (Ju et al., 2017; Papp et al., 2010).

Mengingat pentingnya Se bagi kesehatan, maka fortifikasi Se perlu ditambahkan dalam pangan untuk menghasilkan makanan tinggi Se (Kieliszek \& Blazejak, 2016). Beberapa hasil riset menyatakan bahwa jamur merupakan sumber pangan terbaik untuk fortifikasi Se (da Silva et al., 2012; Nunes et al., 2012; da Silva et al., 2013). Jamur mempunyai kemampuan menyerap senyawa Se dalam jumlah yang besar dan mampu mengubah Se anorganik menjadi Se organik, sehingga aman dikonsumsi (da Silva et al., 2012). Selain itu, jamur juga rendah kalori, kaya akan protein, mineral, dan serat (Deepalakshmi \& Sankaran, 2014).

Salah satu jamur tiram yang rasanya enak dan memiliki nilai jual yang tinggi adalah jamur tiram coklat (Pleurotus pulmonarius dan Pleurotus sajorcaju). Berdasarkan hasil uji laboratorium, kandungan mikronutrien pada jamur tiram meliputi Ca 15,08 mg/kg; Fe 13,99 mg/kg; Zn 12,11 mg/kg;

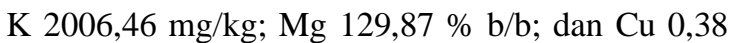
$\mathrm{mg} / \mathrm{kg}$. Diantara mikronutrien tersebut, hanya Se yang belum terdapat dalam jamur tiram. CostaSillva et al. (2011) melaporkan kandungan selenium pada beberapa produk jamur tiram segar yang dijual di pasar hanya berkisar $0,1 \mathrm{ppm}$. Oleh sebab itu, fortifikasi Se pada jamur tiram coklat diperlukan sehingga jamur ini dapat menjadi pilihan sumber pangan sehat bernutrisi lengkap.

Jamur mempunyai potensi pasar yang bagus dan disukai konsumen karena rasanya yang enak serta banyak manfaatnya. Jamur merupakan salah satu pangan substitusi yang mengandung protein tinggi hampir sama dengan daging ayam dan daging sapi (Azmi \& Hidayati, 2014). Pengetahuan masyarakat akan manfaat jamur yang semakin berkembang membuat komoditi jamur semakin meningkat permintaannya (Direktorat Jenderal Hortikultura,
2018). Pada tahun 2015 dengan kenaikan pasar 5\% per tahun, kebutuhan jamur tiram di Indonesia mencapai 21.900 ton/tahun (Piryadi, 2013).

Pada dasarnya, pertumbuhan jamur tiram memerlukan media yang kaya nutrisi yaitu mengandung protein, lemak, serat, abu, mineral penting, dan vitamin (Hoa \& Wang, 2015). Jamur ini tumbuh cepat dalam limbah lignoselulosa seperti tandan kosong kelapa sawit (TKKS) yang tersedia melimpah dan belum dimanfaatkan secara optimal. Nutrisi yang diperlukan jamur tiram untuk tumbuh tersedia pada tandan kosong kelapa sawit (TKKS), sehingga TKKS dapat dimanfaatkan sebagai media tumbuh jamur tiram. Tujuan dari penelitian ini adalah fortifikasi Se dalam jamur tiram coklat yang ditumbuhkan pada media berupa campuran serbuk gergaji dan TKKS sebagai sumber pangan alternatif dalam memenuhi kebutuhan mikronutrien Se dalam tubuh manusia.

\section{Bahan dan Metode}

Pembuatan baglog media pertumbuhan $\mathrm{P}$. pulmonarius dan P. sajor-caju

Baglog media pertumbuhan jamur tiram coklat $P$. pulmonarius dan $P$. sajor-caju dibuat berdasarkan metode Dimawarnita \& Tri Panji (2018) dengan sedikit modifikasi pada perbandingan komposisi media (Tabel 1). Dalam penelitian ini, sodium selenit $\left(\mathrm{Na}_{2} \mathrm{O}_{3} \mathrm{Se}\right)$ digunakan sebagai sumber fortifikasi senyawa Se (10102-18-8, SigmaAldrich) dan ditambahkan dalam campuran media balgog. Terdapat 4 variasi konsentrasi larutan sodium selenit yang diuji, diantaranya: 100, 200, 300 dan 400 ppm dengan tiap perlakuan terdiri dari 8 ulangan atau 8 baglog.

Tandan kosong kelapa sawit (TKKS) yang digunakan untuk penelitian diperoleh dari Pabrik kelapa Sawit PTPN VIII, Kertajaya Banten. TKKS dicacah sehingga berbentuk serabut-serabut kecil, kemudian direndam dan dicuci secara berulang untuk menghilangkan kotoran yang menempel. Selanjutnya, TKKS dicampur dengan bahan - bahan lainnya termasuk sodium selenit, kemudian ditambahkan air sebanyak 40\%. Campuran diaduk hingga homogen. Campuran media kemudian dimasukkan ke dalam plastik dengan berat massa media/substrat per plastik adalah $1 \mathrm{~kg}$.

Tabel 1. Komposisi media tumbuh jamur tiram

Table 1. The composition of oyster mushroom growth media

\begin{tabular}{|c|c|}
\hline $\begin{array}{l}\text { Komposisi } \\
\text { Composition }\end{array}$ & $\begin{array}{l}\text { Persentase (\%) } \\
\text { Percentage (\%) }\end{array}$ \\
\hline TKKS / OPEFB & 46,88 \\
\hline Serbuk gergaji / Sawdust & 46,88 \\
\hline Dedak / Rice bran & 4,46 \\
\hline $\mathrm{CaCO}_{3}$ & 1,34 \\
\hline TSP / Mineral fertilizer & 0,45 \\
\hline
\end{tabular}


Inokulasi dan Inkubasi bibit P. pulmonarius dan P. sajor-caju pada baglog

Inokulasi dan inkubasi dilakukan pada baglog yang sudah disterilisasi dengan autoklaf pada suhu $121{ }^{\circ} \mathrm{C}$ tekanan 1,2 atm selama 1 jam. Bibit jamur tiram coklat $P$. pulmonarius dan $P$. sajor-caju merupakan koleksi CV Asa Agro Corporation di Cianjur, Jawa Barat. Bibit diinokulasi sebanyak 10\% (b/b) dari berat baglog. Baglog jamur tiram coklat kemudian ditutup rapat dan diinkubasi sampai miselium tumbuh memenuhi permukaannya.

Pemanenan tubuh buah P. pulmonarius dan P. sajorcaju

Tutup baglog yang telah dipenuhi miselium dibuka agar tumbuh tubuh buah jamur tiram coklat dari baglog. Tubuh buah yang sudah berukuran besar kemudian dipanen dan ditimbang beratnya. Produktivitas media pertumbuhan jamur tiram ditentukan dengan nilai BER (Biological Efficiency Ratio). Semakin tinggi nilai BER yang dihasilkan maka semakin baik media tersebut. BER dapat dihitung berdasarkan rumus yang dikemukakan oleh Bisaria et al. (1987):

$B E R=\frac{\text { total berat basah jamur yang dipanen }}{\text { berat kering baglog }} \times 100 \%$

Uji pertumbuhan miselium $P$. pulmonarius dan $P$. sajor-caju dalam media PDA berselenium

Sodium selenit dengan variasi konsentrasi 10 , 20, 30, 40, dan 50 ppm ditambahkan ke dalam labu Erlenmeyer berisi media PDA cair dan kemudian diaduk hingga homogen. Media PDA tanpa penambahan sodium selenit digunakan sebagai kontrol. Media PDA cair kemudian disterilkan menggunakan autoklaf pada suhu $121{ }^{\circ} \mathrm{C}$ selama 15 menit pada tekanan 1,21 atm.

Media PDA steril kemudian dituang ke cawan petri berdiameter $9 \mathrm{~cm}$ secara aseptik. Setelah media dingin dan memadat, isolat jamur ( $P$. pulmonarius dan $P$. sajor-caju) diinokulasikan ke dalam media PDA secara aseptik. Cawan petri kemudian diinkubasi pada suhu kamar untuk pengamatan pertumbuhan miselium.

Penentuan kandungan Se organik dan persentase Se terserap pada tubuh buah P. pulmonarius dan $\mathrm{P}$. sajor-caju

Kadar kandungan Se organik pada tubuh buah $P$. pulmonarius dan $P$. sajor-caju diukur menggunakan atomic absorption spectrometer (AAS) (Shimadzu AA 7000) pada panjang gelombang $417 \mathrm{~nm}$ (Saputri \& Afrila, 2017). Persentase senyawa Se terserap pada tubuh buah $P$. pulmonarius dan $P$. sajor-caju dihitung menggunakan rumus berikut:

Persentase Se terserap pada tubuh buah jamur $=$

$\frac{\text { Rerata kandungan Se pada tubuh buah jamur/panen }}{\text { Kandungan selenit yang ditambahkan ke media }} \times 100 \%$

Analisa proksimat dan kandungan mineral

Analisa proksimat dan kandungan mineral dilakukan terhadap tubuh buah jamur tiram cokelat yang difortifikasi sodium selenit. Analisis kadar air, protein, lemak, abu, dan karbohidrat dari sampel jamur tiram berselenium ditentukan berdasarkan metode AOAC (AOAC, 2005). Sedangkan analisis kandungan mineral seperti $\mathrm{Na}, \mathrm{Mg}, \mathrm{Zn}, \mathrm{Fe}, \mathrm{Ca}, \mathrm{K}$, $\mathrm{Cu}$, dan Se ditentukan menggunakan AAS Shimadzu AA 7000 (AOAC, 2005).

\section{Analisa statistik}

Data hasil pengamatan pertumbuhan miselium dan BER yang dihasilkan dianalisis secara statistik menggunakan metode one-way ANOVA pada taraf uji 5\%. Apabila terdapat hasil yang berbeda nyata maka dilanjutkan dengan uji Tukey pada $\alpha=5 \%$.

\section{Hasil dan Pembahasan}

\section{Pertumbuhan miselium jamur}

Rata-rata pertumbuhan miselium tercepat dalam memenuhi permukaan baglog pada $P$. pulmonarius dan $P$. sajor-caju terjadi pada baglog yang ditambahkan sodium selenit 200 ppm, yaitu masingmasing selama 40 dan 37 hari (Tabel 2). Lama waktu bagi $P$. pulmonarius untuk menutupi media baglog dari penambahan sodium selenit 100 dan 200 ppm tidak berbeda nyata. Akan tetapi, pada konsentrasi yang lebih tinggi yaitu 400 ppm memberikan hasil yang berbeda nyata dibandingkan dengan perlakuan Se 200 ppm. Pada konsentrasi tersebut, rata-rata waktu yang dibutuhkan miselium $P$. pulmonarius untuk tumbuh memenuhi baglog menjadi lebih lama, yaitu 64 hari. Pada $P$. sajor-caju, penambahan sodium selenit sebesar 200 ppm memberikan hasil yang berbeda nyata dibandingkan dengan perlakuan lainnya.

Hasil pada Tabel 2 mengindikasikan bahwa pemberian fortifikasi Se sebesar 300 dan 400 ppm menyebabkan lebih lamanya waktu yang diperlukan miselium kedua jamur Pleurotus ini untuk menutupi media di baglog. da Silva et al. (2013) mengemukakan bahwa penambahan selenit dengan konsentrasi yang tinggi dapat menghambat pertumbuhan miselium dan produksi Pleurotus ostreatus. Penghambatan yang terjadi ada kaitannya dengan proses metabolisme Se dimana selenit akan 
tereduksi menjadi hidrogen selenida $\left(\mathrm{H}_{2} \mathrm{Se}\right)$ dan proses oksidasi $\mathrm{H}_{2} \mathrm{Se}$ berlebih mengakibatkan produksi superoksida beracun dan jenis oksigen reaktif lainnya (Milovanović et al., 2014 \& Falandysz, 2008).

Hasil uji pertumbuhan miselium dalam media PDA memperkuat hasil yang diperoleh sebelumnya dimana terdapat perbedaan pertumbuhan miselium yang cukup kontras antara media yang tidak ditambahkan Se (kontrol) dan media berselenium (Gambar 1). Pada hari ke-9, pada kontrol miselium sudah tumbuh memenuhi cawan petri demikian pula pada media yang diperkaya Se 10 ppm juga tumbuh hampir memenuhi cawan petri. Akan tetapi, pada media yang mengandung Se 20-50 ppm, miselium tumbuh jauh lebih sedikit. Selain itu, secara makroskopis juga diamati bahwa miselium dari media kontrol dan media yang diperkaya Se 10 ppm berbentuk seperti kapas putih tipis yang menyebar sedangkan pada konsentrasi Se yang lebih tinggi miselium menebal dan berwarna cokelat kemerahan. Pertumbuhan miselium terhambat yang ditunjukkan dengan semakin berkurangnya pertumbuhan miselium seperti kapas putih tipis. Warna cokelat kemerahan (jingga) yang muncul disebabkan karena presipitasi dari selenium, pada kondisi anaerob terjadi reduksi dari selenit menjadi selenium (Milovanović et al., 2014). Adanya jamur pada media kultur yang diberi selenium akan membantu proses oksidasi senyawa selenit menjadi selenium yang disebut dengan anaerobiosis microsite (da Silva et al., 2019). Selain warna oranye juga dihasilkan bau yang kuat, yang disebabkan karena pembentukan senyawa dimetil selenit $\left(\mathrm{CH}_{3}\right)_{2} \mathrm{Se}$, proses metilasi dari senyawa selenium anorganik menjadi selenium organik volatil yang bersifat lebih tidak beracun dibandingkan bentuk anorganiknya (Zhang \& Chasteen, 1994). Hasil percobaan dalam penelitian ini menegaskan bahwa penambahan sodium selenit pada media tumbuh $P$. pulmonarius dan P. sajor-caju pada konsentrasi berlebih dapat menghambat pertumbuhan miselium kedua jamur tersebut.
Milovanović et al. (2014) menguji pengaruh konsentrasi Se yang tinggi terhadap bentuk morfologi dari jamur tiram putih ( $P$. ostreatus). Hasil penelitiannya menunjukkan bahwa miselium $P$. ostreatus tumbuh baik pada media yang diperkaya Se sebesar 5, 10, dan $20 \mathrm{ppm}$. Sebaliknya, pertumbuhan miseliumnya menjadi sangat terhambat pada konsentrasi Se 100 dan 500 ppm. Hasil pengamatan morfologi menunjukkan miselium pada kontrol berdinding tipis, bercabang, dan berupa hifa dengan sambungan apit (clamp-connections). Pada konsentrasi Se 100 dan 500 ppm, sel hifa pendek, sering bercabang, dengan matriks ekstraseluler yang lebih tebal, dan tanpa sambungan penjepit (Milovanović et al., 2014).

\section{Pertumbuhan tubuh buah jamur tiram coklat} berselenium

Miselium yang telah memenuhi baglog akan membentuk primordia yang selanjutnya menjadi tubuh buah jamur. P. pulmonarius dan P. sajor-caju merupakan jamur tiram coklat yang memiliki siklus hidup seperti jamur tiram putih. Pertumbuhan pleurotus dimulai dengan pertumbuhan benangbenang hifa yang berkumpul membentuk miselium, kemudian dari miselium terbentuk gumpalan kecil yang menyerupai urat akar. Simpul miselia bermuara membentuk bulatan kecil yang disebut pinhead atau biasa disebut dengan fase primordia. Kemudian, dari fase primordia terbentuklah tubuh buah yang sempurna yang memiliki batang (stipe) tanpa cincin dan tudung (pileus) (Dimawarnita \& Perwitasari, 2017). Pileus berbentuk seperti cangkang tiram memiliki ukuran sekitar $5-15 \mathrm{~cm}$ dan permukaan bagian bawah berlapis-lapis seperti insang berwarna putih kecoklatan dan lunak. Panjang dan pendeknya tangkai bergantung pada kondisi lingkungan. Secara visual, kedua jamur tersebut memiliki bentuk dan warna yang serupa. Pada Gambar 2 dapat diamati pula bahwa $P$. pulmonarius dan $P$. sajor-caju dapat tumbuh baik pada media baglog berselenium (100 ppm), ditandai dengan tubuh buah yang cukup banyak dan besar. Hal ini mengindikasikan bahwa

Tabel 2. Rata-rata waktu miselium untuk menutupi media pada baglog P. pulmonarius dan $P$. sajor-caju

Table 2. The average time of mycelium coverage in $\mathrm{P}$. pulmonarius and $\mathrm{P}$. sajor-caju baglog

\begin{tabular}{ccc}
\hline \multirow{2}{*}{$\begin{array}{c}\text { Konsentrasi Se }(\mathrm{ppm}) \\
\text { Se concentration }(\mathrm{ppm})\end{array}$} & \multicolumn{2}{c}{$\begin{array}{c}\text { Rata-rata waktu miselium penuh (hari) } \\
\text { Time average of full mycelium coverage (days) }\end{array}$} \\
\cline { 2 - 3 } 100 & P. pulmonarius & \multicolumn{1}{c}{ P. sajor-caju } \\
200 & $43 \pm 5,29 \mathrm{a}$ & $57 \pm 6,48 \mathrm{~b}$ \\
300 & $40 \pm 4,49 \mathrm{a}$ & $37 \pm 6,2 \mathrm{a}$ \\
400 & $50 \pm 14,97 \mathrm{ab}$ & $51 \pm 8,15 \mathrm{~b}$ \\
& $64 \pm 14,46 \mathrm{~b}$ & $52 \pm 14,22 \mathrm{~b}$ \\
\hline
\end{tabular}

*) Angka dalam kolom yang sama diikuti oleh huruf yang sama berarti tidak berbeda nyata menurut uji Tukey pada $\alpha=0,05$

*) Means in the same column followed by the same letters are not significantly different according to Tukey's test at $\alpha=0.05$ 


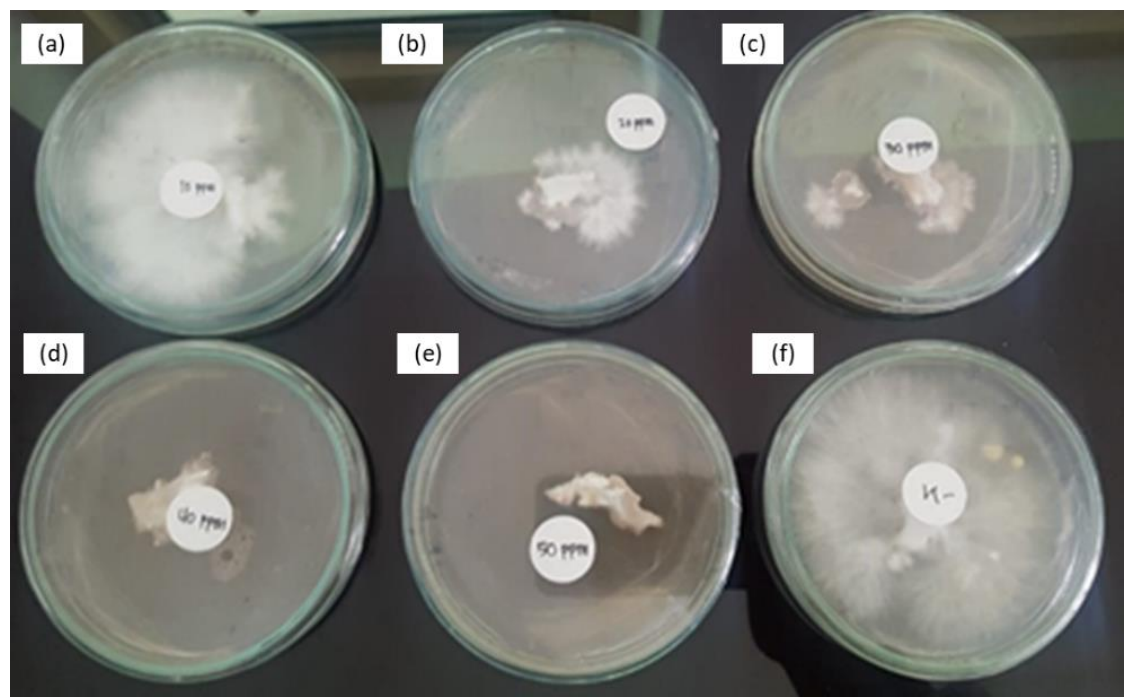

Gambar 1. Pertumbuhan koloni P. pulmonarius hari ke-9 pada media PDA dengan variasi konsentrasi sodium selenit pada cawan petri berdiameter $9 \mathrm{~cm}$ : (a) $10 \mathrm{ppm}$; (b) $20 \mathrm{ppm}$; (c) $30 \mathrm{ppm}$; (d) $40 \mathrm{ppm}$; (e) $50 \mathrm{ppm}$; dan (f) 0 ppm

Figure 1. The growth of P.pulmonarius mycelium at days-9 on PDA medium with concentration variation of sodium selenite on petri dish with diameter $9 \mathrm{~cm}:$ (a) $10 \mathrm{ppm}$; (b) $20 \mathrm{ppm}$; (c) $30 \mathrm{ppm}$; (d) $40 \mathrm{ppm}$; (e) $50 \mathrm{ppm}$; and (f) $0 \mathrm{ppm}$

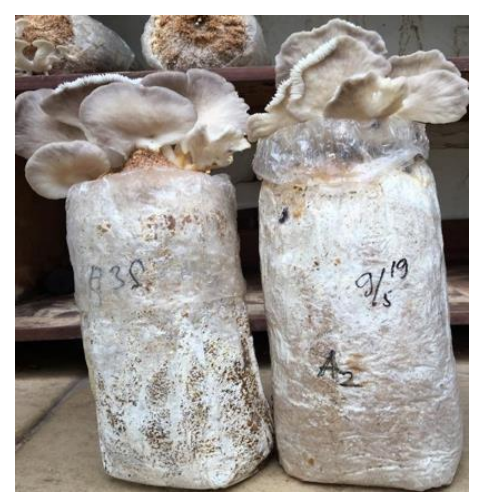

Gambar 2. Tubuh buah jamur tiram: a) P. sajor-caju dan b) $P$. pulmonarius pada media baglog yang difortifikasi Se 100 ppm

Figure 2. Fruiting body of oyster mushroom: a) P. sajorcaju and b) P. pulmonarius on baglog media that fortified with 100 ppm of Se

tubuh buah jamur yang dihasilkan dari baglog dengan fortifikasi sodium selenit 100 ppm tidak mengalami perubahan morfologi secara kasat mata.

Nilai BER tertinggi diperoleh dari baglog yang diperkaya sodium selenit $200 \mathrm{ppm}$ yaitu $18,80 \%(P$. pulmonarius) dan 17,89\% (P. sajor-caju) (Tabel 3). Pada konsentrasi tersebut, rata-rata bobot massa panen tubuh buah $P$. pulmonarius dan $P$. sajor-caju dalam satu periode masing-masing adalah sebesar $134,31 \mathrm{~g}$ dan 127,77 g. Akan tetapi, rata-rata bobot massa panen kedua jamur tidak berbeda nyata antara penambahan sodium selenit 100 ppm dan 200 ppm. Satu periode tumbuhnya jamur dalam penelitian ini adalah sekitar 2 bulan dengan jumlah panen sebanyak 0 sampai 4 kali. Pada penambahan sodium selenit 300 dan 400 ppm, beberapa baglog tidak menghasilkan tubuh buah. Bahkan pada konsentrasi 400 ppm, hanya 2 dari 8 baglog yang menghasilkan tubuh buah. Hal ini membuktikan kandungan Se yang tinggi pada media baglog berdampak pada penghambatan pertumbuhan jamur tiram cokelat.

Niedzielski et al. (2014) melaporkan jamur jenis Agrocybe aegerita dan Hericium erinaceus mampu menghasilkan tubuh buah pada media baglog yang ditambahkan garam Se hingga 0,6 mM (103,76 ppm), sedangkan Ganoderma lucidum dapat tumbuh pada perlakuan konsentrasi garam Se maksimum 0,8 mM (138,35 ppm). Dalam penelitian tersebut, BER umumnya cenderung mengalami penurunan seiring dengan meningkatnya konsentrasi Se pada media tumbuh jamur. Namun, pada konsentrasi garam Se tertentu, nilai BER yang dihasilkan terkadang lebih tinggi dibandingkan dengan kontrol. Niedzielski et al. (2014) melaporkan Nilai BER tertinggi pada $A$. aegerita, $H$. erinaceus, dan $G$. lucidum adalah sebesar 54,50; 54,80 dan 34,83\%, secara berurutan, yang tumbuh pada substrat yang ditambahkan garam selenit dan selenat masing-masing sebanyak 0,1 dan $0,2 \mathrm{mM}$.

Kandungan Se organik dan persentase penyerapan Se pada jamur

Hasil uji kandungan Se menunjukkan bahwa serapan Se tertinggi pada tubuh buah $P$. pulmonarius dan $P$. sojur caju diperoleh dari perlakuan fortifikasi sodium selenit 200 ppm dengan persentase masingmasing sebesar 3,51\% dan 2,31\% (Tabel 4). Persentase serapan Se merupakan parameter penting untuk mengetahui konsentrasi sodium selenit optimum yang perlu ditambahkan ke media baglog jamur. Peningkatan konsentrasi sodium selenit pada 
baglog cenderung meningkatkan kandungan organik pada tubuh buah jamur. Namun pada konsentrasi 300 dan 400 ppm, persentase serapan Se pada $P$. pulmonarius menurun yang mengindikasikan penambahan sodium selenit pada konsentrasi tersebut kurang efisien dalam meningkatkan kandungan Se organik pada jamur.

Hasil Analisis proksimat dan kandungan mineral jamur tiram coklat ( $P$. pulmonarius) berselenium menunjukkan kandungan protein, karbohidrat, energi total, dan selenium yang lebih tinggi dibandingkan dengan jamur tiram coklat yang tidak difortifikasi Se (Tabel 5). Selain itu, juga terjadi penurunan kandungan senyawa $\mathrm{P}_{2} \mathrm{O}_{5}, \mathrm{Na}, \mathrm{Ca}, \mathrm{Fe}, \mathrm{Zn}, \mathrm{K}, \mathrm{Mg}$ dan $\mathrm{Cu}$ pada jamur yg difortifikasi Se. Selain, mengkonsumsi jamur, pemenuhan kebutuhan senyawa-senyawa tersebut dapat dipenuhi dari sumber makanan lain.

Tabel 3. Rata-rata bobot massa panen dan nilai BER P. pulmonarius dan P. sajor-caju dalam dari baglog yang diberi perlakuan sodium selenit

Table 3. The average of harvesting biomass and BER value of $\mathrm{P}$. pulmonarius and $\mathrm{P}$.sajor-caju from baglog that fortified with sodium selenite

\begin{tabular}{lccc}
\hline $\begin{array}{c}\text { Spesies jamur } \\
\text { Mushroom species }\end{array}$ & $\begin{array}{c}\text { Konsentrasi sodium selenit (ppm) } \\
\text { Sodium selenite concentration (ppm) }\end{array}$ & $\begin{array}{c}\text { Bobot biomassa (g) } \\
\text { Biomass weight (g) }\end{array}$ & BER (\%) \\
\hline P. pulmonarius & 100 & $87,64 \mathrm{ab}$ & 12,27 \\
& 200 & $134,31 \mathrm{a}$ & 5,54 \\
& 300 & $39,55 \mathrm{~b}$ & 9,76 \\
\hline P. sajor-caju & 100 & $69,74 \mathrm{ab}$ & 12,21 \\
& 200 & $87,21 \mathrm{a}$ & 17,89 \\
\hline
\end{tabular}

*) Angka dalam kolom yang sama diikuti oleh huruf yang sama berarti tidak berbeda nyata menurut uji Tukey pada $\alpha=0,05$

*) Means in the same column followed by the same letters are not significantly different according to Tukey's test at $\alpha=0,05$

Tabel 4. Kandungan Se organik dan persentase penyerapan Se pada tubuh buah $P$. pulmonarius dan $P$. sajor-caju Table 4. The content of organic Se and percentage of Se absorption in P. pulmonarius and P. sajor-caju fruiting body

\begin{tabular}{lccc}
\hline $\begin{array}{c}\text { Spesies jamur } \\
\text { Mushroom species }\end{array}$ & $\begin{array}{c}\text { Konsentrasi Selenit (ppm) } \\
\text { Selenite concentration (ppm) }\end{array}$ & $\begin{array}{c}\text { Kandungan Se organik } \\
(\mathrm{ppm}) \\
\text { Organic Se content (ppm) }\end{array}$ & $\begin{array}{c}\text { Persentase Serapan (\%) } \\
\text { Absorption percentage (\%) }\end{array}$ \\
\hline $\begin{array}{l}\text { P. pulmonarius } \\
200\end{array}$ & $1,45 \pm 0,66$ & 3,45 \\
& 300 & $7,02 \pm 6,83$ & 2,64 \\
& 400 & $7,91 \pm 7,41$ & 2,33 \\
\hline P. sajor-caju & 100 & $9,34 \pm 3,48$ & 1,33 \\
& 200 & $1,33 \pm 0,52$ & 2,31 \\
\hline
\end{tabular}

- : Tidak ada data karena hampir tidak ada tubuh buah P. sojur-caju yang dihasilkan dari baglog dengan konsentrasi selenit $400 \mathrm{ppm}$

- : No data is available as almost no P. sojur-caju fruiting body was produced from baglog with selenite concentration of 400 ppm 
Tabel 5. Analisis proksimat dan kandungan mineral pada tubuh buah P. pulmonarius dari perlakuan konsentrasi sodium selenit $100 \mathrm{ppm}$

Table 5. Proximate and mineral content analysis of $\mathrm{P}$. pulmonarius fruiting body from the treatment of 100 ppm sodium selenite concentration

\begin{tabular}{|c|c|c|c|}
\hline \multirow{2}{*}{$\begin{array}{l}\text { Parameter } \\
\text { Parameter }\end{array}$} & \multirow{2}{*}{$\begin{array}{c}\text { Satuan } \\
\text { Unit }\end{array}$} & \multicolumn{2}{|c|}{ P. pulmonarius } \\
\hline & & $\begin{array}{c}\text { Tanpa Se } \\
\text { Without Se }\end{array}$ & $\begin{array}{l}\text { Mengandung Se } \\
\text { Containing Se }\end{array}$ \\
\hline Energi dari lemak / Energy from fat & $\mathrm{Kkal} / 100 \mathrm{~g}$ & 20,97 & 4,50 \\
\hline Lemak total / Total fat & $\%$ & 2,33 & 0,50 \\
\hline Protein / Protein & $\%$ & 1,86 & 2,40 \\
\hline Abu / ash & $\%$ & 0,87 & 0,78 \\
\hline Air / water & $\%$ & 93,46 & 87,40 \\
\hline Energi total / Total energy & $\mathrm{Kkal} / 100 \mathrm{~g}$ & 34,33 & 49,78 \\
\hline Karbohidrat / Carbohydrates & $\%$ & 1,48 & 8,92 \\
\hline $\mathrm{P}_{2} \mathrm{O}_{5}$ & $\mathrm{mg} / \mathrm{kg}$ & 2664,18 & 1687,49 \\
\hline $\mathrm{Na}$ & $\mathrm{mg} / 100 \mathrm{~g}$ & 17,24 & $\operatorname{Ttd}$ \\
\hline $\mathrm{Ca}$ & $\mathrm{mg} / 100 \mathrm{~g}$ & 172,64 & 6,87 \\
\hline $\mathrm{Fe}$ & $\mathrm{mg} / 100 \mathrm{~g}$ & 6,52 & 1,23 \\
\hline $\mathrm{Zn}$ & $\mathrm{mg} / 100 \mathrm{~g}$ & 2,04 & 0,78 \\
\hline $\mathrm{K}$ & $\mathrm{mg} / 100 \mathrm{~g}$ & 391,87 & 297,67 \\
\hline $\mathrm{Mg}$ & $\mathrm{mg} / 100 \mathrm{~g}$ & 28,48 & 14,24 \\
\hline $\mathrm{Cu}$ & $\mathrm{mg} / \mathrm{kg}$ & 35,20 & 1,00 \\
\hline $\mathrm{Se}$ & ppm & 0,01 & 1,05 \\
\hline
\end{tabular}

\section{Kesimpulan}

Senyawa selenium dapat difortifikasi pada jamur tiram coklat $P$. pulmonarius dan $P$. sajor-caju melalui penambahan sodium selenit pada baglog jamur. Penyerapan Se tertinggi pada $P$. pulmonarius dan $P$. sajor-caju masing-masing adalah sebesar $3,51 \%$ dan $2,31 \%$ diperoleh dari penambahan sodium selenit $200 \mathrm{ppm}$.

\section{Ucapan Terimakasih}

Kami ucapkan terima kasih kepada Ibu Ida Farida, Yusdyana Putri, dan Irfan (PPBBI) atas bantuannya dalam pelaksanaan penelitian ini. Kami ucapkan terima kasih sebesar-besarnya kepada Kementerian Riset dan Teknologi/Badan Riset dan Inovasi Nasional yang telah mendanai penelitian ini melalui program INSINAS 2019 sehingga penelitian ini dapat berjalan dengan lancar.

\section{Daftar Pustaka}

Choudhary RC, RV Kumaraswamy, S Kumari, A Pal, R Raliya, P Biswas \& V Saharan (2017). Synthesis, characterization, and application of chitosan nanomaterials loaded with zinc and copper for plant growth and protection. Nanotechnology, 10: 227-247.

AOAC (2005). Official methods of analysis. $18^{\text {th }}$ Ed., Washington DC, AOAC INTERNATIONAL.
Azmi N \& R Hidayati (2014). Analisis tingkat permintaan jamur tiram di pasar tradisional dan supermarket di kota Palembang. J Ilmiah AgrIBA 2(9), 169-176.

Bhatia P, F Aureli, MD'Amato, R Prakash, SS Cameotra, TP Nagaraja \& F Cubadda (2013). Selenium bioaccessibility and speciation in biofortified Pleurotus mushroom grown on selenium-rich agricultural residues. Food Chem 140, 225-230.

Bisaria R, M Madan \& VS Bisaria (1987). Biological efficiency and nutritive value of Pleurotus sajor-caju cultivated on different agrowastes. Biol Waste 19, 239-255.

Costa-Sillva F, G Marques, CC Matos, AIRNA Barros \& FM Nunes (2011). Selenium contents of Portuguese commercial and wild edible mushrooms. Food Chemistry 126(1),91-96.

da Silva MCS, J Naozuka, JMR da Luz, LS de Assunção, PV Oliveira, MCD Vanetti, DMS Bazzolli \& MCM Kasuya (2012). Enrichment of Pleurotus ostreatus mushrooms with selenium in coffee husks. Food Chem 131 (2), 558-563.

da Silva MCS, MD Nunes, JMR da Luz \& MCM Kasuya (2013). Mycelial growth of pleurotus 
Spp. in Se-enriched culture media. Adv Microb. 3(11), 11-18.

da Silva MCS, JMR da Luz, APS Paiva, DR Mendes, AAC Carvalho, J Naozuka \& MCM Kasuya (2019). Growth and tolerance of Pleurotus ostreatus at different selenium forms. J Agri Sci 11(2), 151-158.

Deepalakshmi K \& M Sankaran (2014). Pleurotus ostreatus: an oyster mushroom with nutritional and medicinal properties. $J$ Biochem Technol 5(2), 718-726.

Dimawarnita, F \& U Perwitasari (2017). Pemanfaatan tandan kosong kelapa sawit untuk produksi jamur tiram (Pleurotus sp.) dan enzim ligninase. J Mikologi Indonesia 1(2), 105-113.

Dimawarnita F \& Tri Panji (2018). Sintesis karboksimetil selulosa dari sisa baglog jamur tiram (Pleurotus ostreatus). Menara Perkebunan 86(2), 96-106.

Direktorat Jenderal Hortikultura (2018). Laporan Tahunan Direktorat Jenderal Hortikultura Tahun 2018. Jakarta: Kementerian Pertanian.

El Mehdawi AF \& EAH Pilon-Smits (2012). Ecological aspects of plant selenium hyperaccumulation. Plant Biol 14(1),1-10.

Falandysz J (2008). Selenium in edible mushrooms. Journal of Environmental Science and Health 26, 256-299.

Hoa HT \& CL Wang (2015). The effects of temperature and nutritional conditions on mycelium growth of two oyster mushrooms (Pleurotus ostreatus and Pleurotus cystidiosus). Mycobiol 43(1), 14-23.

Ju W, X Li, Z Li, GR Wu, XF Fu, XM Yang, XQ Zhang \& XB Gao (2017). The effect of selenium supplementation on coronary heart disease: a systematic review and meta-analysis of randomized controlled trials. J Trace Elem Med Biol 44, 8-16.

Kemenkes RI (2019). Peraturan Menteri Kesehatan Republik Indonesia nomor 28 tahun 2019 tentang angka kecukupan gizi yang dianjurkan untuk masyarakat Indonesia. Jakarta, Kemenkes RI.

Kieliszek M \& S Błażejak (2016). Current knowledge on the importance of selenium in food for living organisms: a review. Molecules 21(5), $1-16$.
Milovanović I, I Brčeski, M Stajić, A Korać, J Vukojević \& A Knežević (2014). Potential of Pleurotus ostreatus mycelium for selenium absorption. Sci World J, 1-8.

Niedzielski P, M Mleczek, M Siwulski, M Gąsecka, L Kozak, I Rissmann \& P Mikołajczak (2014). Efficacy of supplementation of selected medicinal mushrooms with inorganic selenium salts. J Environ Sci Health 49(12), 929-937.

Nunes RGFL, JMR Luz, RB Freitas, A Higushi, MCM Kasuya \& MCD Vanetti (2012). Selenium bioaccumulation in shiitake mushrooms: a nutritional alternative source of this element. $J$ Food Sci 77(9), 983-986.

Papp LV, A Holmgren \& KK Khanna (2010). Selenium and selenoproteins in health and disease. Antiox Redox Sign 12(7), 793-795.

Piryadi TU (2013). Bisnis Jamur Tiram. Jakarta, Agro Media Pustaka.

Saputri, GAR \& AP Afrila (2017). Penetapan Kadar Kalsium Pada Brokoli (Brassica Oleracea, L.) Segar, Kukus, Dan Rebus Secara spektrofotometri Serapan Atom (SSA). J Analis Farmasi, 2(4), 251-257.

Sitanggang ML (2017). Jangan abaikan mikronutrien. Oktober 31, 2017. Diunduh dari http://www.depkes.go.id/article/view/ 17110100001/jangan-abaikanmikronutrien.html. [19 November, 2018]

Thiry C, A Ruttens, L de Temmerman, YJ Schneider \& L Pussemier (2012). Current knowledge in species-related bioavailability of selenium in food. Food Chemistry 130(4), 767-784.

WHO \& FAO (2006). Guidelines on food fortification with micronutrients. Ed: Allen L, B de Benoist, O Dary, R Hurrell. Geneva.

Yin H, Z Qi, M Li, GJ Ahammed, X Chu \& J Zhou (2019). Selenium forms and methods of application differentially modulate plant growth, photosynthesis, stress tolerance, selenium content and speciation in Oryza sativa L. Ecotox Environ Safe 169, 911-91.

Zhang L \& TG Chasteen (1994). Amending cultures of selenium-resistant bacteria with dimethyl selenone. Appl. Organomet. Chem 8, 501-508. 